\title{
Studi Kinetika Proses Adsorpsi NOM pada Air Permukaan dengan Zeolit dan Karbon Aktif
}

\author{
M. Rangga Sururi, Etih Hartarti, Reza Husyaeri \\ Jurusan Teknik Lingkungan ITENAS, JL. PHH.Mustafa 23, Bandung \\ e-mail: rangsoer@yahoo.com
}

\begin{abstract}
Abstrak
Natural organic matter (NOM) merupakan prekursor produk samping pada proses desinfeksi air minum. Adsorpsi merupakan alternative proses pengolahan pendahuluan untuk menyisihkan NOM dari air baku. Penelitian ini ditujukan untuk mengetahui kinetika adsorpsi media karbon aktif dan zeolit terhadap penyisihan NOM sehingga diketahui media mana yang memiliki efektifitas sorpsi terbesar dalam menyisihkan NOM melalui kinetika adsorpsi.

Pada proses adsorpsi dengan karbon aktif dan zeolit pada NOM dalam air permukaan, model kinetika orde 2 dianggap lebih baik jika dibandingkan dengan model kinetika orde 1, karena memiliki nilai qe (jumlah adsorbat yang teradsorpsi pada waktu setimbang) sebesar 0,29 mg/gr untuk karbon aktif dan 0,336 mg/gr untuk zeolit. Nilai qe tersebut lebih mendekati nilai qe experiment sebesar 0,34 mg/gr. Media zeolit pada percobaan ini dapat menyerap bahan organik alami dalam air permukaan dengan lebih baik dibandingkan dengan karbon aktif, karena zeolit merupakan adsorben polar yang memiliki sifat hidrofilik.
\end{abstract}

Kata kunci: Adsorpsi, setimbang, karbon aktif, zeolit

\section{Pendahuluan}

Air baku dalam proses pengolahan air minum dapat berasal dari air permukaan, air tanah, mata air dan air angkasa. Namun pada umumnya untuk penyediaan air minum skala kota, sumber air baku yang digunakan berasal dari air permukaan dan mata air, sedangkan untuk sistem individual biasanya digunakan air tanah.

Umumnya air tanah, mata air dan air permukaan mengandung bahan organik, baik bahan organik alami (Natural organic matter, NOM) ataupun bahan organik yang berasal dari pencemaran akibat kegiatan anthropogenic. NOM secara garis besar dapat dibagi menjadi dua yaitu: Particulat organic carbon (POC), dengan ukuran diatas $0.45 \mu \mathrm{m}$, biasanya kurang dari 10\% NOM; dan Dissolved organic carbon (DOC). DOC merupakan bagian dari NOM yang sangat mempengaruhi kualitas air. DOC sebagian besar (80\%) terdiri dari materi hidrophobik dan hidrophilik (Shon et al., 2006). Humus merupakan materi yang terkandungm pada hampir dalam setiap sumber air. Humus dapat dihasilkan secara alami dari proses dekomposisi tumbuhan (Anirudhan, 2008).

Bahan organik merupakan prekursor produk samping pada proses desinfeksi air minum. Bahan organik berhalogen ketika bereaksi dengan klor dapat menghasilkan Trihalometan dengan bentuk 
$\mathrm{CHx}_{9}$ dimana $\mathrm{x}$ dapat berupa $\mathrm{Cl}, \mathrm{Br}$ atau $\mathrm{I}$, senyawa ini bersifat karsinogenik sehingga dapat merugikan kesehatan (Roosmini, 1991).

Jika kita menggunakan ozon sebagai desinfektan maka akibat reaksi antara ozon dengan NOM akan membentuk produk samping berupa bahan organik dengan berat molekul rendah, serta dengan adanya ion brom akan terbentuk produk samping berupa bahan halogen yang dapat menimbulkan gangguan terhadap kesehatan (USEPA, 1999). Skema reaksi pembentukan produk samping dengan ozon dapat dilihat pada Gambar 1.

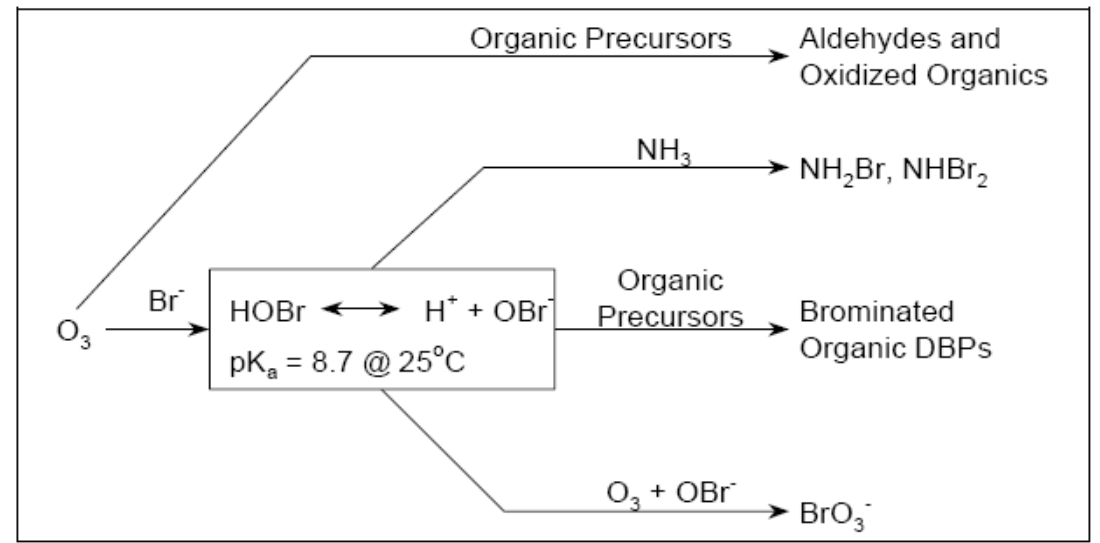

Gambar 1. Skema pembentukan produk samping desinfeksi dengan ozon (USEPA, 1999)

Dari uraian di atas maka sebelum dilakukan proses desinfeksi maka diperlukan proses pendahuluan untuk menyisihkan bahan organik alami yang terkandung dalam air sehingga dapat meminimasi pembentukan produk samping desinfeksi.

Salah satu teknik yang memungkinkan untuk menyisihkan bahan organik dalam air adalah dengan menggunakan teknik adsorpsi. Adsorpsi adalah peristiwa menempelnya suatu zat pada permukaan zat lain karena ketidakseimbangan gaya-gaya pada permukaan. Adsorpsi merupakan suatu proses pemisahan dimana komponen dari fase larutan berpindah ke permukaan fase padatan (Metcalf \& Edy, 1991).

Penelitian ini ditujukan untuk mengetahui kinetika adsorpsi media karbon aktif dan zeolit terhadap penyisihan NOM . Sedangkan tujuannya adalah untuk mengetahui media mana yang memiliki efektifitas sorpsi terbesar dalam menyisihkan NOM melalui kinetika adsorpsi.

\section{Metodologi}

Langkah pengerjaan dalam penelitian ini adalah: 


\section{a. Tinjauan Pustaka}

Pada tahap ini dilakukan identifikasi literatur dan jurnal yang berhubungan dengan penelitian. Hasil studi pustaka ini bermanfaat sebagai dasar-dasar dalam melaksanakan penelitian, serta dapat dijadikan acuan dalam menganalisa data hasil penelitian.

\section{b. Persiapan Penelitian}

Sampel air yang digunakan dalam penelitian ini adalah air permukaan. Pemeriksaan Sampel secara on site dilakukan terhadap parameter kandungan oksigen terlarut (Dissolved Oxygen), $\mathrm{pH}$, kekeruhan dan suhu.

Media yang digunakan dalam penelitian ini yaitu karbon aktif dan zeolit. Ukuran masing-masing media yang digunakan sebesar 1,68 mm-2,38 mm merupakan ukuran yang tersedia di pasaran.

Bahan media yang akan digunakan disaring terlebih dahulu agar ukuran media benar-benar homogen. Setelah itu dilakukan pencucian menggunakan aquades lalu dipanaskan dalam oven dengan suhu $105^{\circ} \mathrm{C}$. Pemanasan dilakukan untuk menghilangkan kadar air dalam media sehingga pori-pori dalam media lebih terbentuk dan kinerja media akan lebih maksimal (Viariawan, 2004).

\section{c. Pelaksanaan Penelitian}

Penelitian ini dilaksanakan di Laboratorium Air Teknik Lingkungan Itenas. Adapun alat dan bahan yang digunakan pada penelitian ini adalah:

- Alat

- $\quad$ Labu erlenmeyer $300 \mathrm{ml}$

- Pemutar (shaker)

- Timbangan

- Bahan

- $\quad$ Media karbon aktif ukuran sedang (1,68 mm-2,38 mm)

- $\quad$ Media zeolit ukuran sedang (1,68 mm-2,38 mm)

- $\quad$ Air aquades

Setelah dilakukan pengukuran kandungan bahan organik pada sampel, kemudian media yang sudah ditimbang seberat 30 gram dimasukkan kedalam labu erlenmeyer $300 \mathrm{ml}$ yang sudah terisi air sampel sebanyak $300 \mathrm{ml}$. Labu erlenmeyer tersebut kemudian ditempatkan diatas shaker (v = 105 rpm). Sebelum penelitian inti dilakukan terlebih dahulu dilakukan penelitian pendahuluan untuk mengetahui nilai jumlah adsorbat yang teradsorpsi pada waktu setimbang (qe) experiment. 
Pengukuran kandungan bahan organik dilakukan dalam rentang waktu selama 1 jam, 3 jam, 6 jam, 24 jam, dan 48 jam. Pengukuran bahan organik dilakukan dengan metode titrasi permanganometri.

\section{d. Analisa Data}

Data hasil penelitian ini dianalisa dengan menggunakan kinetika adsorpsi untuk melihat laju (kecepatan) adsorpsi yang terjadi. Banyak model kinetika yang telah dapat menggambarkan reaksi orde dari sistem adsorpsi berdasarkan solusi konsentrasi dan kapasitas dari adsorben. Persamaan kinetika ini ada 2 jenis yang biasa digunakan yaitu kinetika orde reaksi satu dan kinetika orde reaksi dua (Bulut, Ozacar, dan sengil, 2008). Dalam studi ini, dicari mana yang lebih sesuai untuk data penelitian adsorpsi yang didapat.

- Reaksi orde satu

Reaksi orde satu adalah suatu reaksi yang kecepatannya bergantung hanyalah pada salah satu zat yang bereaksi. Atau sebanding dengan salah satu pangkat reaktannya. Persamaan orde reaksi satu dinyatakan dalam rumus sebagai berikut (Bulut, Ozacar, dan Sengil, 2008):

$\frac{d q_{t}}{d t}=k_{1}\left(q_{e}-q_{t}\right)$

Setelah diintegrasikan dan diaplikasikan pada saat terjadinya penyisihan adsorbat oleh adsorben yaitu dari waktu $(\mathrm{t})=0$ sampai $\mathrm{t}=\mathrm{t}$ dan besarnya penyisihan pada saat $\mathrm{t}=0\left(\mathrm{q}_{0}\right)$ sampai $\mathrm{q}=\mathrm{q}_{\mathrm{t}}$, maka persamaan diatas menjadi:

$q_{t}=q_{e}\left(1-e^{-k_{1} t}\right)$

Untuk mendapatkan nilai $\mathrm{k}_{1}$ dalam menganalisis data kinetika nantinya maka persamaan (2-6) harus diubah menjadi bentuk persamaan linear, yaitu:

$\ln \left(q_{e}-q_{t}\right)=\ln q_{z}-k_{1} t$

dengan:

$\mathrm{q}_{\mathrm{e}}=$ jumlah adsorbat yang teradsorpsi pada waktu equilibrium (mg/gr)

$\mathrm{q}_{\mathrm{t}}=$ jumlah adsorbat yang teradsorpsi pada $\mathrm{t}$ waktu (mg/gr)

$\mathrm{k}_{1}=$ laju adsorpsi (1/jam)

$\mathrm{t} \quad$ = waktu (jam) 
Kemudian plot kedalam grafik $\ln \left(\mathrm{q}_{\mathrm{e}}-\mathrm{q}_{\mathrm{t}}\right)$ terhadap $\mathrm{t}$ sehingga terjadi hubungan linear antara titiktitiknya yang dapat digambarkan sebagai garis trendline nya untuk mendapatkan persamaan garis lurus $(\mathrm{y}=\mathrm{mx}+\mathrm{b})$ sehingga nilai slope, gradien dan interceptnya dapat diketahui.

- Reaksi orde dua

Reaksi orde dua adalah suatu reaksi yang kelajuannya berbanding lurus dengan hasil kali konsentrasi dua reaktannya atau berbanding langsung dengan kuadrat konsentrasi salah satu reaktannya. Jika mekanisme adsorpsi yang terjadi adalah reaksi orde dua dimana kecepatan adsorpsi yang terjadi berbanding lurus dengan dua konsentrasi pengikutnya atau satu pengikut berpangkat dua. Laju kinetika adsorpsi reaksi orde dua dapat dinyatakan dalam persamaan berikut (Bulut, Ozacar, dan sengil, 2008):

$\frac{d q_{t}}{d t}=k_{2}\left(q_{e}-q_{t}\right)^{2}$

Hasil integrasi persamaan diatas diaplikasikan setelah terjadinya ikatan maka persamaan tersebut menjadi (Bulut, Ozacar, dan sengil, 2008):

$\frac{1}{\left(q_{e}-q_{t}\right)}-\frac{1}{q_{e}}+k_{2} l$

Dengan bentuk persamaan linearnya(Bulut, Ozacar, dan sengil, 2008):

$$
\frac{t}{q_{t}}=\frac{1}{k_{2} q_{e}^{2}}+\frac{1}{q_{e}} t
$$

dengan:

$\mathrm{k}_{2}=$ kesetimbangan laju adsorpsi reaksi orde dua (g/mg jam)

$\mathrm{t} \quad=$ waktu (jam)

$\mathrm{q}_{\mathrm{e}}=$ jumlah adsorbat yang teradsorpsi pada waktu equilibrium (mg/gr)

$\mathrm{q}_{\mathrm{t}}=$ jumlah adsorbat yang teradsorpsi pada t waktu (mg/gr)

Persamaan (6) diatas juga dapat menyatakan efektifitas penyisihan adsorbat oleh adsorben. Jika persamaan (6) dapat diaplikasikan dengan data penelitian yang ada maka grafik dari $\mathrm{t} / \mathrm{q}_{\mathrm{t}}$ terhadap t akan membentuk sebuah garis lurus yang linear yang merupakan garis trendline dari titik-titik yang ada, dari garis tersebut dapat diketahui nilai $\mathrm{q}_{\mathrm{e}}$ dan $\mathrm{k}_{2}$ dari persamaan garis lurus $(\mathrm{y}=\mathrm{mx}+\mathrm{b})$ yang merupakan nilai slope dan gradiennya. 


\section{Hasil dan Pembahasan}

\subsection{Karakteristik sampel air}

Karakteristik sampel air permukaan yang digunakan dapat dilihat pada Tabel 1.

Tabel 1. Karakteristik Air Sampel

\begin{tabular}{|c|c|c|c|c|c|}
\hline \multirow{2}{*}{ DO $(\mathrm{mg} / \mathrm{L})$} & \multirow{2}{*}{ Suhu $\left({ }^{0} \mathrm{C}\right)$} & \multirow{2}{*}{$\mathrm{pH}$} & \multirow{2}{*}{ Kekeruhan $(\mathrm{NTU})$} & \multicolumn{3}{|c|}{ Organik } \\
\cline { 4 - 6 } & & $\mathrm{KMNO}_{4}(\mathrm{~mL})$ & Konsentrasi Rerata $(\mathrm{mg} / \mathrm{L})$ \\
\hline 0,2 & 26,2 & 6,32 & 55 & 5,2 dan 4,8 & 67,15 \\
\hline
\end{tabular}

Dari tabel diatas dapat dilihat sampel air memiliki kandungan organik awal sebesar 67,15 mg/L. Pada penelitian ini parameter lain yang mempengaruhi proses adsorpsi seperti $\mathrm{pH}$, kekeruhan dan suhu dibiarkan pada kondisi alami dan tidak dikondisikan.

\subsection{Kinetika adsorpsi bahan organik pada sampel air}

Untuk menentukan mekanisme dan laju adsorpsi suatu media maka dibutuhkan suatu pendekatan dengan menggunakan model kinetika (Bulut, Ozacar, dan sengil, 2008). Pada penelitian ini kinetika yang dibahas yaitu dengan kinetika reaksi orde satu dan kinetika reaksi orde dua. Berdasarkan hasil percobaan didapatkan nilai qe experiment yang merupakan nilai penyisihan adsorbat per adsorben untuk zeolit dan karbon aktif pada kondisi kesetimbangan sebesar 0,34 mg/gr.

\subsubsection{Adsorpsi bahan organik dengan media karbon aktif}

\section{a. Reaksi orde satu adsorpsi bahan organik dengan media karbon aktif}

Penentuan reaksi orde satu dilakukan dengan regresi linier menggunakan persamaan 3. Regresi linier kinetika reaksi orde ke satu pada proses penyisihan bahan organik dengan menggunakan media karbon aktif dapat dilihat pada Gambar 2.

Dari Gambar 2 diatas dapat dilihat bahwa persamaan garis yang didapatkan dari linearisasi adalah $\mathrm{y}=-0,024 \mathrm{x}+1,869$ dengan $\mathrm{R}^{2}=0,975$. Dari persamaan garis tersebut dapat diketahui nilai $\mathrm{k}_{1}$ yaitu $0,024 \mathrm{l} / \mathrm{menit}$ dan nilai qe dari persamaan tersebut (qe teoritis) sebesar 0,15 mg/gr.

\section{b. Reaksi orde dua adsorpsi bahan organik dengan media karbon aktif}

Penentuan reaksi orde dua dilakukan dengan regresi linier menggunakan persamaan 6. Regresi linier untuk kinetika reaksi orde dua pada proses penyisihan bahan organik dengan menggunakan media karbon aktif dapat dilihat pada Gambar 3. 


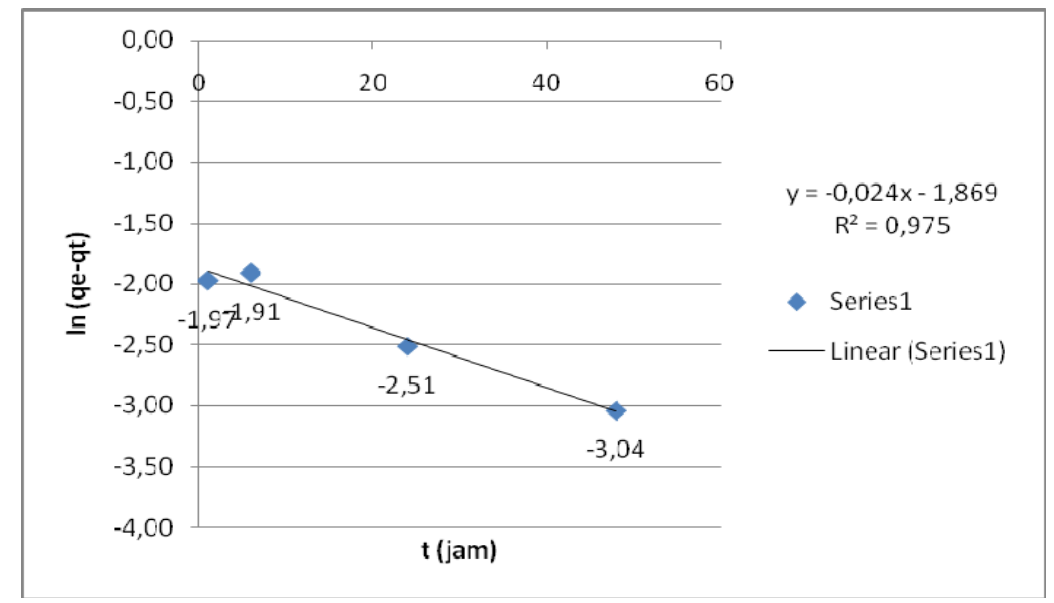

Gambar 2. Kurva ln $\left(\mathrm{q}_{\mathrm{e}}-\mathrm{q}_{\mathrm{t}}\right)$ terhadap t pada media karbon aktif

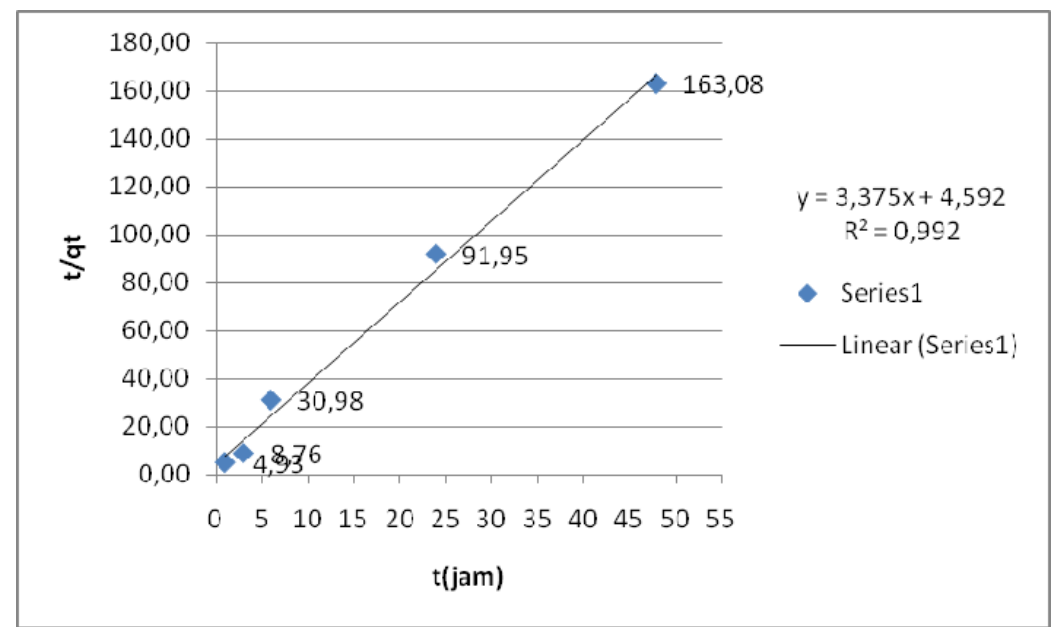

Gambar 3. Kurva $\mathrm{t} / \mathrm{q}_{\mathrm{t}}$ terhadap t pada media karbon aktif

Dari Gambar 3 dapat dilihat bahwa persamaan garis berdasarkan hasil linearisasi adalah y = 3,375x $+4,592$ dengan $\mathrm{R}^{2}=0,992$. Dari persamaan garis tersebut dapat diketahui nilai gradien dan slopenya adalah 3,375 dengan nilai interceptnya adalah 4,592. Sehingga nilai $\mathrm{m}=1 / \mathrm{q}_{\mathrm{e}}$ dan $\mathrm{b}=$ $1 /\left(\mathrm{k}_{2} \mathrm{q}_{\mathrm{e}}{ }^{2}\right)$ artinya nilai $\mathrm{k}_{2}$ sebesar 2,48 $\mathrm{gr} /(\mathrm{mg} \mathrm{jam})$, dan qe dari persamaan tersebut (qe teoritis)sebesar 0,29 mg/gr.

\subsubsection{Adsorpsi bahan organik dengan media zeolit}

\section{a. Reaksi orde satu adsorpsi bahan organik dengan media Zeolit}

Penentuan reaksi orde satu dilakukan dengan regresi linier menggunakan persamaan 3, berdasarkan hasil percobaan didapatkan nilai qe yang merupakan nilai penyisihan adsorbat per adsorben pada kondisi kesetimbangan sebesar 0,34 mg/gr. Regresi linier untuk mendapatkan nilai k dapat dilihat pada Gambar 4. 


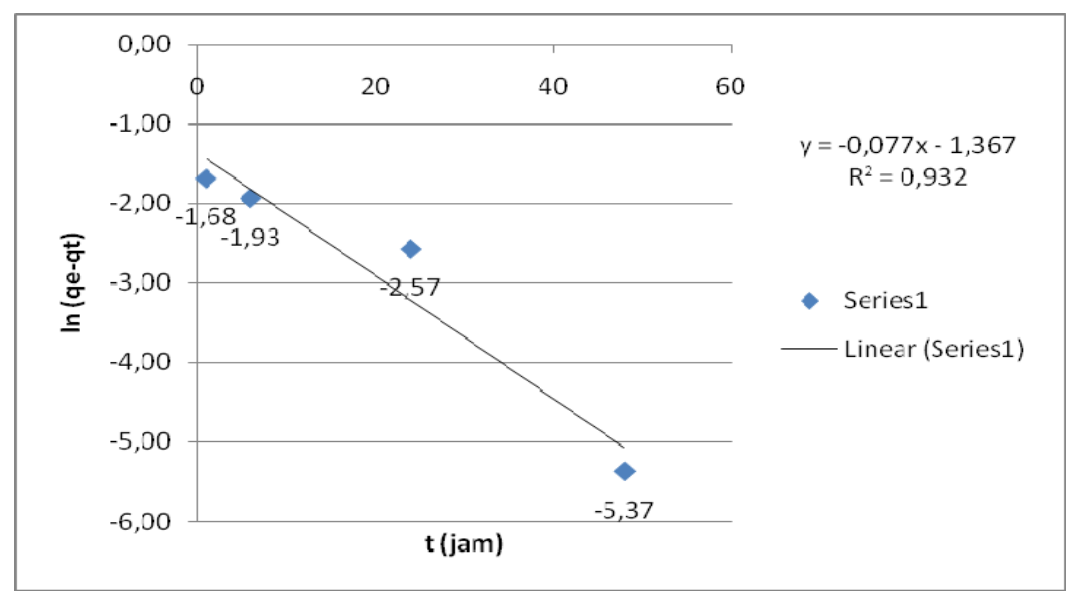

Gambar 4. Kurva ln $\left(\mathrm{q}_{\mathrm{e}}-\mathrm{q}_{\mathrm{t}}\right)$ terhadap t pada media zeolit

Dari Gambar 4 dapat dilihat bahwa persamaan garis berdasarkan hasil linearisasi adalah y = -0,077x $-1,367$ dengan $\mathrm{R}^{2}=0,932$. Dari persamaan garis tersebut dapat diketahui nilai $\mathrm{k}_{1}$ yaitu 0,077 l/min dan qe dari persamaan tersebut (qe teoritis)sebesar 0,25 mg/gr. Besaran nilai $\mathrm{k}_{1}$ menyatakan besarnya laju adsorpsi media zeolit terhadap konsentrasi organik.

\section{b. Reaksi orde dua adsorpsi bahan organik dengan media zeolit}

Penentuan reaksi orde dua dilakukan dengan regresi linier menggunakan persamaan 6, perhitungan regresi linier untuk mendapatkan nilai k dapat dilihat pada Gambar 5.

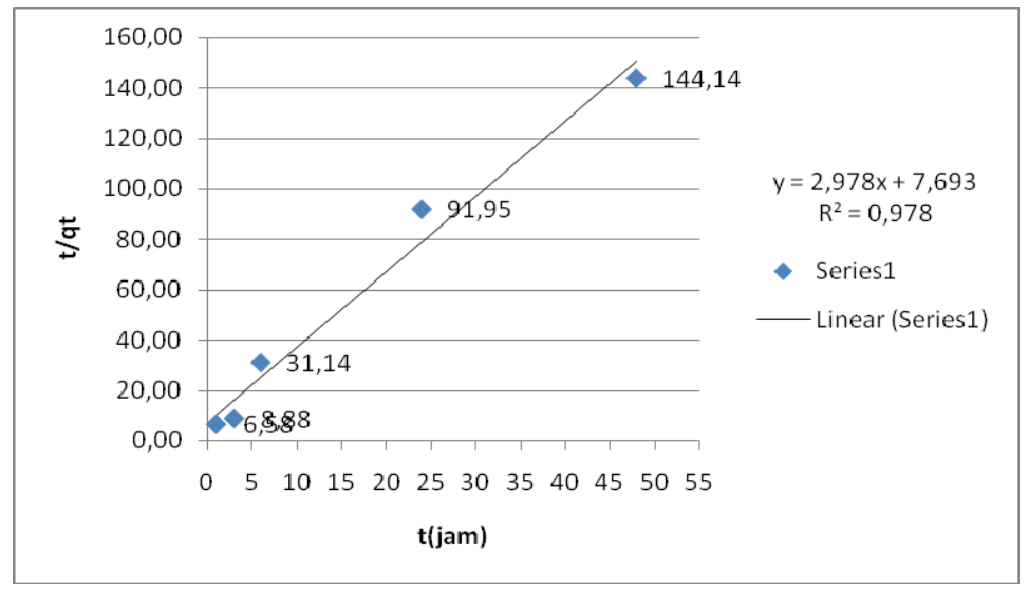

Gambar 5. Kurva t/qt terhadap t pada media zeolit

Dari Gambar 5 dapat dilihat bahwa persamaan garis hasil linearisasi adalah: $y=2,978 x+7,693$, dengan $\mathrm{R}^{2}=0,978$. Dari persamaan tersebut dapat diketahui nilai slope dan gradiennya adalah 2,978 dengan nilai interceptnya adalah 7,693. Jika dilihat dari bentuk persamaan garis lurus $(\mathrm{y}=\mathrm{mx}$ + b) terhadap persamaan model kinetika reaksi orde dua maka nilai $m=1 / q_{e}$ dan dan $b=1 /\left(k_{2} q_{e}{ }^{2}\right)$ sehingga nilai $\mathrm{k}_{2}$ dapat diketahui yaitu sebesar 1,15 gr/(mg jam), dan qe dari persamaan tersebut (qe teoritis) sebesar $0,336 \mathrm{mg} / \mathrm{gr}$. 


\subsection{Perbandingan Model Kinetika Adsorpsi Masing-masing Media}

Berdasarkan penelitian yang dilakukan didapat persamaan garis lurus dari data-data yang telah diaplikasikan terhadap kedua persamaan kinetika adsorpsi. Masing-masing media dilakukan pendekatan untuk mengetahui kapasitas dan laju adsorpsinya dengan menggunakan model kinetika reaksi orde satu dan kinetika reaksi orde dua.

Untuk mengetahui model kinetika yang cocok untuk diterapkan pada penelitian ini maka dilakukan komparasi hasil model regresi yang didapatkan sebelum ditentukan media mana yang paling cocok untuk proses adsorpsi bahan organik alami pada air permukaan. Tabel 2 merupakan komparasi parameter kinetika pada orde satu dan orde dua.

Tabel 2. Komparasi parameter kinetika pada setiap adsorben

\begin{tabular}{|c|c|c|c|c|c|c|c|}
\hline \multirow{2}{*}{ Jenis Adsorben } & \multirow{2}{*}{$\begin{array}{c}\text { qe,exp } \\
(\mathrm{mg} / \mathrm{gr})\end{array}$} & \multicolumn{3}{|c|}{ Kinetika Orde 1} & \multicolumn{3}{c|}{ Kinetika Orde 2 } \\
\cline { 3 - 8 } & $\begin{array}{c}q_{1} \\
(\mathrm{mg} / \mathrm{gr})\end{array}$ & $\begin{array}{c}K_{1} \\
(\mathrm{l} / \mathrm{min})\end{array}$ & $R_{1}{ }^{2}$ & $\begin{array}{c}q_{2} \\
(\mathrm{mg} / \mathrm{gr})\end{array}$ & $\begin{array}{c}K_{2} \\
(\mathrm{gr} / \mathrm{mg} \cdot \mathrm{min})\end{array}$ & $R_{2}{ }^{2}$ \\
\hline Karbon Aktif & 0.34 & 0,15 & 0,024 & 0,975 & 0,29 & 2,48 & 0,992 \\
\hline Zeolit & 0.34 & 0,25 & 0,077 & 0,932 & 0,336 & 1,15 & 0,978 \\
\hline
\end{tabular}

Berdasarkan tabel 2, di antara kedua model kinetika adsorpsi dapat dilihat bahwa model kinetika baik orde 1 dan orde 2 memiliki nilai $\mathrm{R}^{2}$ diatas 0,95, artinya koefisien korelasi yang menyatakan kekuatan atau derajat hubungan antara peubah bebas dan peubah terikat pada regresi untuk ke-2 orde reaksi tersebut memiliki tingkat hubungan sangat kuat. Namun jika dilihat nilai kesetimbangan antara qe experiment (0,34 mg/gr) dan $\mathrm{q}_{1}$ hasil dari orde 1 dan $\mathrm{q}_{2}$ hasil dari orde 2 maka nilai yang paling mendekati qe experiment adalah hasil dari model kinetika orde 2 masing-masing sebesar 0,29 mg/gr untuk karbon aktif dan 0,336 mg/gr untuk zeolit.

Pada Tabel 2 dapat dilihat komparasi kapasitas adsorpsi antara ke-2 media, maka zeolit pada percobaan ini dapat menyerap bahan organik alami dalam air permukaan dengan lebih baik dibandingkan dengan karbon aktif. Kondisi tersebut terjadi karena zeolit merupakan adsorben polar yang memiliki sifat hidrofilik, dibandingkan dengan karbon aktif yang non polar dan bersifat hidropfobik (Viariawan, 2004).

\section{Kesimpulan dan Saran}

Kesimpulan dan saran dari hasil penelitian adalah:

1. Kinetika pada proses adsorpsi dengan media karbon aktif dan zeolit terhadap bahan organik alami dalam air permukaan untuk model orde 1 dan 2 memiliki nilai korelasi yang sangat kuat dengan nilai $\mathrm{R}^{2}$ diatas 0,95 . 
2. Pada proses adsorpsi dengan karbon aktif dan zeolit pada bahan organik alami dalam air permukaan, model kinetika orde 2 dianggap lebih baik jika dibandingkan dengan model kinetika orde 1, karena memiliki nilai $\mathrm{q}_{2}$ yang lebih mendekati nilai qe hasil percobaan,

3. Media zeolit pada percobaan ini dapat menyerap bahan organik alami dalam air permukaan dengan lebih baik dibandingkan dengan karbon aktif, karena zeolit merupakan adsorben polar yang memiliki sifat hidrofilik.

4. Diperlukan penelitian lanjutan, dengan melakukan penelitian dengan memperhatikan parameter $\mathrm{UV}_{254}$ dalam menentukan kandungan zat organik selain menggunakan metode titrimetri sebagai perbandingan.

\section{Daftar Pustaka}

Bulut Emrah, Ozacar Mahmut, Sengil Ayhan I. (2008). Adsorption Of Malachite Green Onto Bentonite: Equilibrium And Kinethics Studies And Process Design. Microporous And Mesoporous Materials. Elsevier. 115. 234-256.

Metcalf dan Edy. (2004). Waste Water Engineering: Treatment And Reuse. Singapore: McgrawHill.

Roosmini Dwina. (1991). Pembentukan Senyawa Trihalometan dalam Air Permukaan, Tesis Magister, Departemen Teknik Lingkungan ITB, Bandung.

Shon, H kyong., Erdei, L.., Kim, Jong-Ho. (2006). Constituent of natural organic matter (NOM) and its effect in water, Journal korean Ind, engineering, chemical, 17, 119-124.

T.S. Anirudhan, P.S. Suchithra, S. Rijith. (2008). Amine-modified polyacrylamide-bentonite composite for the adsorption of humic acid in aqueous solutions. Elsevier. 326. 147-156.

USEPA. (1999). Alternative disinfectants and oxidants guidance manual, EPA, 815-R-99-014.

Viariawan, Febbi A. (2004). Studi Pemanfaatan Tempurung Kelapa Sawit Sebagai Bahan Dasar Karbon Aktif Granular Pada Pengolahan Akhir Limbah Cair Cold Rolling Mill. Bandung: Tugas Akhir Teknik Lingkungan ITB.

Yuri Irawan dan Petrus. (2004). Pengolahan Limbah Zat Cair Warna (Disperse Red 17) di Industri Tekstil Melalui Proses Adsorpsi Dengan Zeolit dan Karbon Aktif Sebagai Adsorben. Bandung: Tugas Akhir Teknik Kimia Itenas. 